\title{
The Comic Function of Chivalric Names in Don Quijote
}

\section{HOWARD MANCING}

C

ONTEMPORARY READERS OF Don Quijote can unquestionably appreciate more fully the comic effect achieved by the utilization of dozens of chivalric names when they are made aware of their sources and connotations and of how thoroughly they permeate the work. The repetition of such names helps evoke the world of knight-errantry, and the names themselves are a significant stylistic factor and a major source of parody in the novel. ${ }^{1}$

The chivalric names in Don Quijote may be divided into four categories: (1) historical chivalric personages, (2) characters from the European literary epic and chivalric tradition, especially from the Spanish Romancero, (3) characters specifically from Spanish romances of chivalry, and (4) the chivalric names invented by Cervantes in Don Quijote. ${ }^{2}$ I propose to

1 Parody has been defined as "a humorous and aesthetically satisfying composition in prose or verse, usually written without malice, in which, by means of a rigidly controlled distortion, the most striking peculiarities of subject matter and style of a literary work, or author, or a school or type of writing, are exaggerated in such a way as to lead to an implicit value judgment of the original." J. G. Riewald, "Parody as Criticism," Neophilologus, 50 (1966), 128-29.

${ }^{2}$ For a complete listing of all of these names, together with the chapters of Don Quijote in which they appear, see Appendices I-IV. Particularly useful in compiling these lists were the following: Julio Cejador y Frauca, La lengua de Cervantes: Tomo II - Diccionario y comentario (Madrid: Establecimiento Tipográfico de Jaime Ratés, 1906); Armando Cotarelo Valledor, Padrón literatio de Miguel de Cervantes Saavedra (Madrid: Instituto de España, 1948); Richard L. Predmore, An Index to "Don Quijote" Including Proper Names and Notable Matters (New Brunswick: Rutgers University Press, 1938); and several editions of Don Quijote, particularly those of Martín de Riquer (Barcelona: Juventud, 1958), Francisco Rodríguez Marín, 10 vols. (Madrid: Atlas, 1947-49), and Diego Clemencín (Madrid: Castilla, 1966), and the indices of José Bergua (Madrid: Ediciones Ibéricas, 1965). Categorization was not always easy. The Cid and Roland, for example, are simultaneously historical and fictional personages, but as the historical Cid had more substance for Cervantes, who did not know the epic Poema de Mio Cid, than did (or does for us) the historical Roland, known primarily to Cervantes through the Romancero and Ariosto and Boyardo, the former is listed in Appendix I and the latter in Appendix II. The same process of categorization, admittedly arbitrary, has been used throughout; see Carlomagno, Turpín, Artús, etc. Certain historical figures such as Carlos V and Juan de Austria could be considered chivalric, but that role is not stressed when they are mentioned (e.g., in the Captive's tale) in the novel. Other names presented particular problems. For example, the "famoso moro Muzaraque" (I, 29, 297), has defied identification, but Rodríguez Marín (II, p. 382, n. 5) deems it likely that he is a "fantástico protagonista de alguna antigua conseja oral que Cervantes escuchara en su niñez," and so is placed in Appendix II. The apparent name Maglimo (never identified) is generally assumed to be a typographical error for the adjective maligno ( $\mathrm{I}, 18,166)$, and is therefore not included. Solisdán (I, elogio, 33) 
analyze the names in the fourth category in order to demonstrate the subtlety and profundity of Cervantes' comic artistry. For the purposes of this study I have subdivided the chivalric names invented by Cervantes in his novel as follows: (a) major names, (b) Don Quijote's onomastic inventions, (c) chivalric names created by other characters, and (d) corruptions of chivalric names.

\section{Major names}

The inhabitants of the world created by Cervantes include a middleaged gentleman named, perhaps, Alonso Quijano, a peasant farmer, Sancho Panza, and the peasant girl called Aldonza Lorenzo. Supposedly writing the verdadera historia of these characters is one Cide Hamete Benengeli. The elderly gentleman determines to rebel against reality and to create for himself a new identity and a new name, Don Quijote de la Mancha. Similarly, he rechristens his horse, inventing the name Rocinante, and the girl he selects to love, Dulcinea del Toboso. Thus the author and character share the responsibility for the names which dominate the novel.

Cervantes suggests no fewer than five apellidos for his hidalgo: Quijada, Quesada, Quejana, Quijana, Quijano (I, 1, 36 ; I, 5, 62; II, 74, 1063). ${ }^{3}$ The name Quijote evokes several simultaneous comic images, appending as it does the augmentative and pejorative suffix -ote to the stem of the names mentioned above. The word quijote itself means an appropriately chivalric piece of armor worn to cover the thigh. ${ }^{4}$ At one point Don Quijote mentions the well-known historical chivalric figure of Gutierre Quijada and adds: "de cuya alcurnia yo deciendo por línea recta de varón" (I, 49, 497). Dámaso Alonso has suggested as a possible source for Cervantes' protagonist the ridiculous knight-errant Camilote from Primaleón and Gil Vicente's Don Duardos. ${ }^{5}$ Although this onomastic parallel would not have

may be a printing error for Solimán, the emperor of Trapisonda who appears in several chivalric romances, or, equally likely, it may be a burlesque onomastic invention of Cervantes. The lines are blurred when Cervantes has Dorotea identify her father, the king of Micomicón (an invented name), as Tinacrio el Sabidor (I, 30, 303), a character from the romances of chivalry. A similar case is that of the giant Malambruno (II, 39, 820), from the invention of the Dueña Dolorida, who has a previous literary existence.

${ }^{3}$ All references to Don Quijote in the text and notes are to the edition by Riquer cited in note 2 , and indicate part, chapter, and page number.

${ }^{4}$ Constantino Láscaris Comneno believes that it is in this capacity, and using the word in a metaphoric sense, that Cervantes intended the name. "El nombre de don Quijote," A Cerv, 2 (1952), 364.

${ }^{5}$ He sees the following similarities between these two characters: (1) both are hidalgos, (2) both go forth in search of adventures and need to be dubbed knights-errant, (3) both are ridiculously in love, (4) both make others swear that their lady is the most beautiful in the world, (5) both are extravagant, ridiculous figures, (6) both are accorded a similar reception by the rest of the world, and (7) there is the parallelism in nomenclature. "El hidalgo Camilote y el hidalgo don Quijote," RFE, 20 (1933), 392-93. 
pleased Cervantes' protagonist, he was flattered by a similar one with the name of Lanzarote del Lago ${ }^{6}$ and such knights as Angriote, Galeote, and Marlote from Amadis de Gaula. Finally, the addition of de la Mancha is a practice, as Don Quijote himself points out (I, 1, 40), perfectly suited to knight-errantry. To underscore the comic, the barren sterility of La Mancha, a word derived from the Arabic manxa "dry land," both establishes a parallel with the character - recall "seco de carnes" (I, 1, 36) and parodies the lavish forest setting so frequently found in the romances of chivalry. ${ }^{7}$ A better choice than Don Quijote de la Mancha, so replete with comic connotations, would be difficult to imagine.

When Sancho Panza bestows upon his master the name of El Caballero de la Triste Figura (I, 19, 175) both Don Quijote and the reader are pleased; Don Quijote because it is proper for knights-errant to adopt significant new names, and the reader because the new name so aptly describes the character. Although Don Quijote lists a series of such names adopted by the heroes of the chivalric romances, he does not observe that Belianís de Grecia once took the name El Caballero de la Rica Figura, or that Ceocliano, from Clarin de Landanis, is once cited as El Caballero de la Triste Figura. ${ }^{8}$

Later Don Quijote changes his name to El Caballero de los Leones, saying that "en esto sigo la antigua usanza de los caballeros andantes, que se mudaban los nombres cuando querían, o cuando les venía a cuento" (II, 17, 659). The name certainly is much more heroic and comes at the end of an adventure where Don Quijote displays genuine, if misdirected, valor. Considerable humor for the reader results from the association made by Cide Hamete Benengeli, when he compares the mad knight with the famous historical figure Don Manuel de León (II, 17, 657). In addition, there are three knights-errant in the Spanish romances of chivalry who called themselves "de los Leones" and others simply "del León."

Dulcinea can be derived from Aldonza, which means dulce "sweet" (a word Don Quijote uses to describe the dama to whom he, as a knighterrant, is obliged to pay homage, I, 1, 40-41), and the termination -ea to establish a parallel with poetic literary heroines such as Melibea, Dorotea, and Galatea. However, in order to avoid the infelicitous evocation of words like jalea, gragea, or oblea (all three syllables, as opposed to the four syllable poetic names) and to create a name more "músico y pere-

- Leo Spitzer is convinced that the character saw his name in this way. "Linguistic Perspectivism in the Don Quijote," in Linguistics and Literary History (Princeton: Princeton University Press, 1948), p. 49.

7 See Joaquín Casalduero, Estudios de literatura española (Madrid: Gredos, 1962), p. 71, and Federico Sánchez-Escribano, "Dos notas cervantinas," A Cerv, 8 (1959-60), 365.

8 Francisco Rodríguez Marín, "El Caballero de la Triste Figura y el de los Espejos," in Estudios cervantinos (Madrid: Atlas, 1947), p. 376. 
grino" (I, 1, 41), it was necessary to interpose the diminutive -in- between the stem and the suffix. ${ }^{9}$ Another source for the name might have been the shepherd and shepherdess Dulcino and Dulcina from Los diez libros de Fortuna de amor (1573) by Antonio Lofrasso, one of the books in Don Quijote's library (I, 6, 74).

Another level of significance for the name Aldonza, and one often unnoticed by twentieth-century readers, is the vulgarity associated with the name. The prostitute heroine of La Lozana andaluza was so named because "Lozana es nombre más común, y comprehende su nombre primero Aldonza, o Alaroza en lengua arábiga." 10 Popular proverbs attest to the low esteem in which the name was held: A falta de moza, buena es Aldonza; Moza por moza, buena es Aldonza; Aldonza, con perdón; Aldonza sois, sin vergüenza.

The addition of the geographic epithet del Toboso is even more comic than the addition of de la Mancha to Don Quijote's name. Whereas the latter is at least a region in Spain, the former is merely a very small town of absolutely no distinction. Toboso is the adjectival form of toba "tufa," a type of porous limestone deposit; ${ }^{11}$ but it can also mean tartar incrustations on the teeth. Thus the name Dulcinea del Toboso renders a marvellous contradiction in terms: "sweet" in the first element and "tartartoothed" (suggesting "foul-breathed") in the second. In the same way that Don Quijote changes the concept of the peasant girl of whom it was said that she had "la mejor mano para salar puercos que otra mujer de toda la Mancha" (I, 9, 93), to an ideal gentle lady, so he similarly transforms the cacophonous Aldonza Lorenzo into the euphonious (yet ironically self-contradictory) Dulcinea del Toboso. The parallel comic effect on both conceptual and linguistic levels is considerable.

Sancho Panza can perhaps suggest a comic juxtaposition of Sancho, the name of a series of medieval Castilian kings, and the vulgar panza "belly" (or zancas "shanks," cited once in the manuscript, I, 9, 94). But if the name Sancho reminds one of Spanish royalty, it also evokes, and much more strongly, two images which reinforce its origin among the lower classes. The first is the numerous proverbs based on the name: Allá va Sancho con su rocino; Topado ha Sancho con su rocin; Topado ha Sancho con la horma de su zapato; Con lo que Sancho sana, Domingo adolece; Al buen callar Ilaman Sancho; Revienta Sancho de hidalgo; etc. The other image is the Manchegan sancho in the sense of puerco "pig." Rojas Villandrando, borrowing from Juan de Arjona, writes in 1603: "Pues Sancho,

9 Rafael Lapesa, “Aldonza-Dulce-Dulcinea," BBMP, 23 (1947), 32.

10 Francisco Delicado, La Lozana andaluza, ed. Bruno Damiani (Madrid: Castalia, 1969), p. 250.

11 Such a deposit may be found on the stones of a dry stream bed, quite possibly the source for the name of the town of Toboso in La Mancha. 
puerco y cochino / todo es uno. ..." 12 Probably the concept of a rustic named Pig Belly or Pig Shanks is largely responsible for the squire's reputation, only partially deserved, as a glutton. It is also possible that Cervantes was familiar with a celebration by the university students at Salamanca described in the Tragicomedia de Lisando y Roselia (1542): "Panza es un sancto que celebran los estudiantes en la fiesta de Santantrugo, que le llaman sancto de hartura." 13

Cide Hamete Benengeli, the supposed Arabic historian who is the "author" of Don Quijote, is a name thoroughly appropriate for the author's purpose. Frequently the romances of chivalry are purported to have been translated from exotic languages, and Belianis de Grecia is presented as having been originally written in Arabic by the sabio Fristón. ${ }^{14}$ The elements of the name may also be significant: Cide (sidi "my lord"), Hamete (Jhamed, a proper name meaning "he who praises"), and Benengeli (perhaps from ben "son" and andjeli "of the angel," or simply an equivalent of berengena "eggplant").

The name Rocinante that Don Quijote gives his horse conveys a subtle nuance of comic chivalry. For the knight-errant the combination of the words rocin ("nag") and antes (in the dual sense of "formerly" and "first") - although the perceptive reader notes that ante is a gerundive, not adjectival, form - results in the horse who was formerly a nag and now is first among all nags. Underscoring the chivalric context, the name also parallels the -ante (Agramante, Bradamante, Morgante, Olivante, and Tirante), and to a lesser extent the -arte (Durandarte and Lisuarte) and -onte (Rodamonte) literary names.

Whereas the comic connotations of the major names are generally apparent even to casual readers, the less common ones, in fact virtually every name associated with matters of chivalry, when scrutinized carefully, also reveal humorous elements that place them well within the boundaries of the same type of comedy.

\section{Don Quijote's onomastic inventions}

During his career Don Quijote invents a number of names for the imaginary characters of his chivalric world. Many, but not all, of these names occur in his classic description - Pedro Salinas calls it "un magnífico friso épico" 15 - of the two armies which turn out to be flocks of sheep. These names share certain linguistic features: extravagant length

12 See Francisco Rodríguez Marín, "Dos poemitos de Juan de Arjona," BRAE, 23 (1936), 352, 373-74.

13 Cited by Cejador, p. 810.

${ }^{14}$ In the 1614 apocryphal sequel to Don Quijote, the author, who imitated Cervantes in so many ways, also created an Arabic chronicler, named Alisolán.

15 "El polvo y los nombres," $C A, 11$, No. 5 (Sept.-Oct., 1952), p. 213. Several specific points in the following paragraphs are borrowed from this excellent essay. 
(Brandabarbarán, Caraculiambro, Espartafilardo, etc.); titles referring to nonexistent kingdoms (Boliche, Malindrania, Quirocia, etc.); alliteration (Alifanfarón, Brandabarbarán, Brocabruno, etc.); stress on the final syllable (Alfeñiquén, Alifanfarón, Pentapolín, etc.); and nasal sounds (Alfeñiquén, Alifanfarón, Brandabarbarán, etc.).

The most effective element in the creation of comedy in these names, however, is their etymological humor: Alifeñiquén (from alfeñique "sugar paste"); Alifanfarón (from Ali, a common Arabic name, and fanfarrón "swaggering" or "showy"); Brandabarbarán (from brando "sword," an element common in chivalric names, and bárbaro "barbaric" or perhaps Barbarán, a knight-errant from Florisel de Niquea); Brocabruno (from brocal, the metal ring of the scabbard of a sword, and bruno "dark brown," another typical chivalric onomastic element); Espartafilardo (from Esparta "Spartan," and the past participle of hilar [from filar] "to spin"); Laurcalco (from laurel "laurel," and calco "tracing" or "imitation"); Micocolembo (from mico "monkey," or mi "my" and coco "bogy," and lembo, a type of small boat); Miulina (from miau "mew," and -ina, a feminine suffix): Pentapolín (from Pentápotis, the five cities, and -in, an incongruous diminutive); Pierres Papín (a Frenchman who, in the late sixteenth century, owned a card shop in Sevilla); and Timonel de Carcajona (from timonel "helmsman," and carcajada "guffaw").

In the romances of chivalry there abound such names as Quirieleisón de Montalbán, Placerdemivida, Reposada (all cited in I, 6, 72), Aduqueperec, Cataquefarás, and Fesinpiedad from Tirante el Blanco, Famongomadán, Madafabul, Quinorante, and Salustanquidio from Amadis de Gaula, Pintiquiniestra (cited in I, 6, 68) from Amadis de Grecia, Contumeliano de Fenicia from Belianis de Grecia, and many more. E. C. Riley characterizes such names as "a half-hearted self-mockery and a crude pre-Cervantine irony." 16

In addition, the chivalric names of Amadis de Gaula, and also of other romances, are characterized by certain common prefixes and suffixes. Of these, the following are employed by Don Quijote: Al- (Alfeñiquén, Alifanfarón); Bran- (Brandabarbarán), -in (Pentapolín), -ón (Alifanfarón), -án (Brandabarbarán), and -el (Timonel). ${ }^{17}$ The use of epithets as they are with these names, to indicate nationality (Algarbe, Trapobana, las tres Arabias), ${ }^{18}$ personal characteristics (de la Gran Fuerza), appearance (del Arremangado Brazo), etc., is also common in chivalric romances. ${ }^{19}$

16 Cervantes' Theory of the Novel (Oxford: Oxford University Press, 1962), p. 23.

17 Barton Sholod, "A Study of the Language of Amadis de Gaula," unpublished Master's thesis, Columbia University, 1954, pp. 97, 100-01.

18 Trapobana, the three Arabias, the Puente de Plata, Persia (although the Memelukes are from Egypt), and Garamanta all appear in one or more romances of chivalry.

19 Sholod, pp. 105-06. 
When describing the life of a typical knight-errant to Sancho, Don Quijote offers the following as representative names: El Caballero de la Sierpe and El Caballero del Sol $(\mathrm{I}, 21,197) .{ }^{20}$ Don Diego de Miranda is referred to several times in narration as El del Verde Gabán, which Don Quijote modifies to chivalric form: El Caballero del Verde Gabán (II, 17, 661 ). All of these names possess a ring of general familiarity for readers of the romances of chivalry.

In a class by themselves are the river Guadiana and the lagoons of Ruidera. In his dream-fantasy of the Cave of Montesinos Don Quijote makes the former a squire and the latter a dueña, both tearful at the death of Durandarte, who are converted by Merlín into external geographic manifestations of their profound grief (II, 23, 706).

Don Quijote is never at a loss to coin a chivalric name, and those he invents to inhabit his world of fantasy are not only brilliant examples of onomastic humor, but they are equally brilliant imitations and parodies of names commonly found in chivalric literature.

\section{Chivalric names created by other characters}

The priest Pero Pérez, the barber Maese Nicolás, Dorotea, the tricksters at the ducal palace, and Sansón Carrasco, in order to deceive and manipulate Don Quijote, voluntarily step into the roles of chivalric characters. In order to appear authentic in such roles they must talk in a chivalric style and employ chivalric names. Since they have all read and are familiar with the style and content of the romances of chivalry, and since they have Don Quijote as a model, they adapt readily to the situation. The priest gives Dorotea the name Princesa Micomicona, "porque llamándose su reino Micomicón, claro está que ella se ha de llamar así" (I, 29, 293). This is the same process used in the formation of the names of Amadís de Gaula, Don Quijote de la Mancha, and others. ${ }^{21}$ The comic effect of the names Micomicón and Micomicona (from mico "monkey") is obvious.

When improvising her story, Dorotea identifies her father as Tinacrio el Sabidor (an enchanter who has a role in more than one chivalric romance), her mother as Jaramilla (a diminutive of the Jarama river), and her arch-enemy as Pandafilando (from pando "slow moving," and the present participle of hilar [from filar] "to spin") de la Fosca Vista (I, 30, 303). The whole Micomicona episode is merely a ruse to make Don Qui-

${ }^{20}$ There are two examples of a Caballero del Sol and one Caballero de la Sierpe in the romances of chivalry. When Don Quijote describes a typical chivalric adventure for the Canon of Toledo, the name Caballero del Lago is used in narration $(I, 50,503)$ and is thus the name implied, but never actually used, by Don Quijote in his story.

${ }^{21}$ Sancho Panza puts this practice into perspective: "No hay duda en eso ... que yo he visto a muchos tomar el apellido y alcurnia del lugar donde nacieron, llamándose Pedro de Alcalá, Juan de Úbeda y Diego de Valladolid, y esto mesmo se debe de usar allá en Guinea: tomar las reinas los nombres de sus reinos" (I, 29, 293). 
jote return home, and when for this is substituted the simpler method of "enchanting" him, the barber plays the role of the enchanter who delivers the prophesy of the sabia Mentironiana (from mentirón "big lie").

Sansón Carrasco is first called the Caballero del Bosque when he and Don Quijote meet in the forest (II, 12, 621) and, just once, the Caballero de la Selva (II, 14, 630). Only after the dawn when Don Quijote can see his mirror-like armor is he called the Caballero de los Espejos (II, 14, 636). During this adventure Sansón never calls himself by any of these names, nor does Don Quijote employ them when addressing the knight. ${ }^{22}$ Only after the battle does Tomé Cecial, Sansón's squire, refer to the "caballero de los Espejos" (II, 14, 639); after they part Don Quijote uses the same name (II, 16, 643). Names of this sort are very common in the romances of chivalry. There is one example of a knight, Platir, being called the Caballero del Espejo. When Sansón meets Don Quijote again in Barcelona and announces his name as El Caballero de la Blanca Luna, he cruelly refuses to give a name to his lady: "Mi dama, sea quien fuere" (II, 64, 1010-11), making the defeat just that much more bitter for Don Quijote.

Of the adventures staged for Don Quijote in the palace of the Duke and Duchess, the most elaborate is that of the Dueña Dolorida (also known as the Countess Trifaldi because of her skirt and the Countess Lobuna ${ }^{23}$ because of the wolves of her earldom [had they been foxes she would have been called the Countess Zorruna]) and her squire Trifaldín de la Barba Blanca, whose name is apparently derived form that of his mistress and from his appearance. ${ }^{24}$ Other characters in this cast include the king Archipiela (from archipiélago "archipelago"), the queen Maguncia (the Spanish version of the German city of Mainz), ${ }^{25}$ the princess Antonomasia (whose name speaks for itself), the knight Don Clavijo (from clavija "peg"), the giant Malambruno (from malo "evil," and bruno "dark brown"), and the wooden horse Clavileño (from clavija, and leño "log") ${ }^{26}$ el Alígero (a poetic adjective meaning "winged" which simultaneously contains the adjective ligero "light") (II, 38-40, 815-25).

${ }^{22}$ Chivalric nomenclature cannot fail to filter in this manner into the narration. After the ragged Cardenio is seen in the Sierra Morena the narrator calls him the Roto de la Mala Figura (I, 27, 224) in order to establish a parallel with the Caballero de la Triste Figura. He is subsequently referred to, only in narration, as the "astroso caballero de la Sierra" (I, 24, 225) and El Caballero del Bosque (I, 24, 226). See also n. 20.

${ }^{23}$ The -una termination here and in Zorruna might partake of the pejorative augmentative -ona. Cervantes seems to sense the development of Latin $u>o$ and the consequent archaic - and comic - effect of -una.

${ }^{24}$ Spitzer points out, however, that Trifaldín is derived from the commedia dell-arte figure of Truffaldino, and thus Trifaldi is a regressive form of the squire's name. "Linguistic Perspectivism," pp. 48-49.

${ }^{25}$ Although perhaps not significant as concerns Cervantes' awareness, it may be worth noting that the termination -uncia is from the Latin -untia. 
The extended adventure of Altisidora (from alta "high" or altísima "most high," and Isidora, a feminine name) and her accomplice Emerencia (from eminencia "eminence") simultaneously subjects Don Quijote to great humiliation and makes manifest his moral and spiritual superiority over the idle-rich ducal pair.

There is just one occasion on which Sancho Panza has recourse to the invention of a chivalric name: it comes when he attempts to talk his way out of accompanying his master on Clavileño. His line of reasoning is that in the romances of chivalry the presence of the squire on an adventure is never mentioned; rather, he says, it is recorded simply that "Don Paralipomenón de las Tres Estrellas acabó la aventura de los seis vestiglos" (II, 49, 826). The erudite Greek etymology of the name (which means "that which has been left out of the body of a work and added as a supplement"), in some editions accented Paralipómenon, makes it particularly incongruous, and therefore comic, on the lips of the uncultured squire.

\section{Corruptions of chivalric names}

A rôle frequently played by Sancho Panza is that of "prevaricador del buen lenguaje" (II, 19, 674). An example of what Sancho does to names is provided by the famous "bálsamo de Fierabrás," which Sancho changes into "aquella bebida del feo Blas" (I, 15, 137), thus making a strangesounding name into one appropriate for someone of Sancho's intellectual and social level. ${ }^{27}$ Later he changes the queen Madásima and the maestro Elisabat (mentioned by Cardenio and Don Quijote in I, 24, 232) into "aquella reina Magimasa o como se llama" and "aquel abad" (I, 25, 234). Magimasa (from magia "magic," and masa "dough") is an excellent example of linguistic humor produced unconsciously on the part of a character. In the case of aquel abad ("that abbot"), a surgeon's name is modified so as to change it into another profession, in a generic sense. ${ }^{28}$

\footnotetext{
${ }^{26}$ Another more complicated, and less likely, possible etymology for Clavileño has been suggested to me: clavel "carnation" (perhaps suffering contamination with clavo "nail") and the suffex -eño indicating place of birth (as in malagueña "girl from Málaga"), thus rendering something like "the horse from the land of the carnations."

27 Spitzer calls this phenomenon "polyonomasia": "Sancho must multiply names simply because all the forms of names that he retains are only approximations to the real ones; they are variable because he cannot take a firm hold on them; he indulges in what linguists call 'popular etymologies,' i.e. he alters names according to the associations most convenient to his intellectual horizon. Sometimes he offers several variations, but even when only one alteration is involved, the effect of polyonomasia still remains because of the fact that the real name is also present in the reader's minds." "Linguistic Perspectivism," p. 45.

${ }^{28}$ This name seems particularly prone to confusion, showing up in English as Mr. Elizabeth and Mrs. Elizabeth. John J. O'Conner, Amadis de Gaulle and its Influence on Elizabethan Literature (Rutgers: Rutgers University Press, 1970), pp. 21-22.
} 
Mambrino, whose helmet Don Quijote believes to have won in fair combat, becomes, for Sancho, Malandrino (from malandrín "evildoer") (I, 19, 170), Martino (from Martin, the common name) (I, 21, 195), and Malino (from malo or maligno "wicked") (I, 44, 457), although he also correctly calls him Mambrino (I, 25, 239). Pandafilando de la Fosca Vista, the giant's name invented by Dorotea, is turned by Sancho into Pandahilado (I, 30, 305), changing the archaic chivalric $f$ - to $h$-, "in accord with the feeling he has acquired for linguistic correspondences between his master's speech and his own," ${ }^{29}$ and also changing the termination from a present to a past participle.

Early in Part II, Sancho reports to his master that their exploits have been published in a volume written by one Cide Hamete Berenjena (II, 2, 557). One meaning of Benengeli (see above) is berenjena ("eggplant"), and Sancho observes that "por la mayor parte he oído decir que los moros son amigos de berenjenas" (II, 2, 557).

When Sancho first hears of the Countess Trifaldi he immediately makes the etymologically correct popular transposition of her name to Tres Faldas and adds the variant Tres Colas, explaining that "en mi tierra faldas y colas, colas y faldas, todo es uno" (II, 37, 810). Near the conclusion of this adventure, while on his own exploratory voyage into unknown celestial regions on Clavileño, Sancho gets flustered and momentarily corrupts the name of Magalona, offering Magallanes (the explorer Magellan), before correcting himself (II, 41, 834). ${ }^{30}$

The same type of error, and with the same effect, can be seen in the following exchange between Don Quijote and his housekeeper:

Dijo también que se llamaba el sabio Muñatón.

- Frestón diría - dijo don Quijote.

- No sé - respondió el ama - si se llamaba Frestón o Fritón;

sólo sé que acabó en tón su nombre. (I, 7, 78)

\footnotetext{
${ }^{29}$ Spitzer, p. 78, n. 15. Earlier in the novel Sancho had changed the poetic name Fili into hilo "thread" (I, 23, 217).

30 Interestingly, the Sancho Panza of Alonso Fernández de Avellaneda's apocryphal Don Quijote (ed. Francisco G. Salinero, Madrid: Castalia, 1971) creates the same "polyonomasia": Fierablas for Fierabras (p. 134), Perineo for Perianeo (p. 384), Membrillo for Mambrino (p. 385), and "harto de pámpanos" for Archipámpano (p. 413). When, in an adventure staged for Don Quijote, there is a character named Bramidán de Tajayunque (p. 181), Sancho Panza, in a brilliantly comic series, coins the following corruptions: Partejunques, Comejunques (p. 185), Tragajunques (p. 186), and Parteyunques (p. 190). However, whereas for the authentic, Cervantine Don Quijote it is near blasphemy to err on a name, the knight-errant presented by Avellaneda is at times hardly better than his squire: Elicebad for Elisabat (p. 127) and Lirgando for Lirgandeo (p. 129), both of which names Don Quijote cited correctly in 1605 .
} 
The variants Fritón (from frito "fried") ${ }^{31}$ and Muñatón (from Muñatones, probably a popular Celestina-type figure) ${ }^{32}$ are especially suitable for the housekeeper to employ. Earlier when Don Quijote returns home from his first sally badly beaten he calls upon the sabia Urganda, from Amadis de Gaula, to cure bim, but the housekeeper replies, "Suba vuestra merced en buena hora, que, sin que venga esa hurgada, le sabremos aquí curar" $(\mathrm{I}, 5,65)$. The word hurgada (from the past participle of hurgar and carrying here the connotation of a meddling woman) is a corruption of the name Urganda that has definite, yet easily overlooked, comic effect. ${ }^{33}$ In the same scene, Don Quijote's niece says Esquife ("skiff") instead of Alquife, for the enchanter from Amadis de Gaula (I, 5, 65).

Other characters corrupt the name of Don Quijote, either purposefully, with animosity, or accidentally, because of a faulty memory. Dorotea almost loses the effect of her story when, at the end, she forgets Don Quijote's name and says, "El cual se había de llamar, si mal no me acuerdo, don Azote, o don Gigote" (I, 30, 303). The first alternative, azote ("whip"), brings to mind an ironic recollection of the adventure of the whipping of Andrés and perhaps even foreshadows the disenchantment of Dulcinea, particularly the scene where Don Quijote himself tries to whip Sancho. Gigote (a kind of minced meat dish) is comic and degrading enough, but it might also recall gigante and the famous windmill episode. Similarly, Dorotea has difficulty remembering Dulcinea del Toboso and calls her "aquesa señora Tobosa" (I, 30, 308).

When Don Quijote interrupts the reading of the Curioso impertinente by fighting wineskins-giants, the innkeeper, Juan Palomeque el Zurdo, enraged by his material losses, calls the mad knight "don Quijote, o don diablo" (I, 35, 363). The offensive priest at the ducal palace maliciously refers to Don Quijote as "este don Quijote, o don Tonto, o como se llama" (II, 31, 768).

${ }^{31}$ The housekeeper is as close to the original as is Don Quijote in this case, as the enchanter's name is actually Fristón. The most probable explanation for Don Quijote's error is simply that Cervantes remembered the name incorrectly.

32 Francisco de Quevedo has written a sonnet beginning "Por no comer la carne sodomita" for the tomb of "la madre Muñatones de la Sierra," who seems to have been a hereticwitch-prostitute. Obras completas: I, Poesía original, ed. José Manuel Blecua (Barcelona: Planeta, 1963), p. 622. Similarly, there is a reference in one version of the Buscón to a Celestina-type by the name of "Muñatones la de Salamanca." See Herman Iventosch, "Onomastic Invention in the Buscón," $H R, 29$ (1961), 20-21. Finally, Quevedo is the author of an Entremés de la vieja Muñatones, first published in Eugenio Asensio's Itinerario del entremés (Madrid: Gredos, 1965), pp. 286-94.

${ }^{33}$ Clemencín (p. 1054, n. 26) notes: "En las ediciones primitivas del año 1605 se lee Urgada y no Urganda, como pusieron otras posteriores, sin advertir que la equivocación añadía gracia al discurso, y era muy verosímil en boca del Ama, quien, como mujer ignorante, no fué extraño que estropease los nombres, sustituyendo en esta ocasión al de Urganda otro de significación y uso común y, por consiguiente, más natural para ella." 
The Dueña Dolorida, when she first enters the scene, employs a series of eight comic superlative endings, finishing with a flourish: "el acendradísimo caballero don Quijote de la Manchísima y su escuderísimo Panza" (II, 38, 814). By this time Sancho Panza will not be repressed by anyone, and responds by escalating the use of superlatives, employing six in a smaller number of words, including "el don Quijotísimo" (II, 38, 841).

The constant repetition of the names discussed in this article must have functioned not only to provide a constant source of humor, but also to serve as a continuous and ironic reminder of the romances of chivalry for seventeenth-century readers of Cervantes' novel. Readers today can enjoy the novel even more than they normally relish it if they make the effort to recognize and appreciate stylistic elements from the chivalric romances, including not only names, but also archaisms, epithets, formulae, etc. The true greatness of Cervantes' art is such that even when these vital thematic and stylistic aspects of the novel are ignored, Don Quijote touches the hearts and minds of men as have few works of literature in the history of the world.

\section{APPENDIX I: HISTORICAL CHIVALRIC PERSONAGES}

[Conde de Aremberg] (Caballero del Grifo) (I, 19)

Pedro Barba (I, 49)

Carlomagno (I, 48, 49; II, 24, 26)

Bernardo del Carpio (I, 1, 25, 49; II, 32)

Cid Ruy Díaz de Vivar (I, 1, 19, 49; II, 22, 33)

Mosén Luis de Falces (I, 49)

Fernán González (I, 49)

Gonzalo Fernández (Hernández) de Córdoba (Gran Capitán) (I, 32, 35, 49)

Diego García de Paredes (I, 32, 49, 51)

Garcilaso de la Vega (I, 49)

Godofre de Bullón (I, 48)

Fernando de Guevara (I, 49)

Gonzalo de Guzmán (I, 49)

Micer Jorge (I, 49)

Monsiur de Lautrec (I, 35)

Manuel de León (I, 49; II, 17)

Juan de Merlo (I, 49)

Rodrigo de Narváez $(\mathrm{I}, 5)$

Diego Ordóñez de Lara (II, 27)

Pepino $(I, 48)$

Diego Pérez de Vargas (Machuca) (I, 8)

Garci Pérez de Vargas (I, 49)

Mosén Pierres, señor de Charní (I, 49)

Gutierre Quijada (I, 49)

Suero de Quiñones (I, 49)

Mosén Enrique de Remestán (I, 49)

Turpín (I, 6, 7, 49; II, 1)

Vellido Dolfos (I, 27, 28; II, 27) 
APPENDIX II: CHARACTERS FROM THE EUROPEAN LITERARY EPIC AND CHIVALRIC TRADITION, ESPECIALLY FROM THE SPANISH ROMANCERO

Abindarráez (I, 5)

Agramante (I, 26, 45)

Angélica la Bella (I, elogio, 10, 25, 26; II, 1)

Artús (Arturo) de Inglaterra (I, 13, 49)

Astolfo (I, 25)

Belerma (II, 22, 23)

Bradamante (I, 25)

Brunelo (II, 4, 27)

Calaínos (II, 9)

Carloto (I, 5)

Cervino (I, 13)

Conde Dirlos (II, 20)

Durandarte (II, 22, 23, 24)

Fierabrás (I, 10, 17, 49)

Floripes (I, 49)

Gaiferos (II, 25, 26, 64)

Galalón (I, 1, 27, 28)

Ginebra (I, 13, 16, 49; II, 19, 23)

Guarino Mezquino $(\mathrm{I}, 49)$

Guy de Borgoña (I, 49)

Iseo $(I, 49)$

Jarifa (I, 5)

Lanzarote del Lago (I, 2, 13, 49; II, 19, 23, 31)

Magalona (I, 49; II, 40, 41)

Malambruno (II, 39, 40, 41)

Mambrino (I, 10, 21, 25, 30, 37, 44, 45, 46)

Marqués de Mantua (I, 5, 10; II, 23, 38)

Marsilio (II, 26, 27)

Medoro (I, 25, 26; II, 1)

Melisendra (II, 25, 26, 64)

Merlín (II, 23, 35, 36, 40, 41, 48, 59, 60, 63, 72)

Montesinos (II, 18, 22, 23, 24, 34, 35, 48, 55)

Morgante $(\mathrm{I}, 1 ; \mathrm{II}, 1)$

Muzaraque (I, 29)

Pierres de Provenza (I, 49; II, 40)

Roldán (Orlando, Rotolando) (I, elogio, 1, 7, 13, 25, 26, 49; II, 1, 8, 26, 32, 40, 66)

Quintañona (I, 13, 16, 49; II, 23)

Reinaldos de Montalbán (I, 1, 6, 7, 33; II, 1, 32, 40)

Rodamonte (II, 1)

Rugero (II, 1, 40)

Sacripante (I, 10; II, 1, 4, 27)

Sobrino (I, 45; II, 1)

Conde Tomillas (I, 16)

Tristán (I, 49)

Valdovinos (Baldovinos) (I, 5, 10; II, 23) 


\section{APPENDIX III: CHARACTERS SPECIFICALLY FROM SPANISH ROMANCES OF CHIVALRY}

Agrajes (I, 8)

Alastrajarea (II, 32)

Alquife (I, 43; II, 34)

Amadís de Gaula (Beltenebros) (I, elogio, 1, 6, 13, 15, 20, 24, 25, 26, 27, 43, 49, 50, 52;

II, $1,2,6,32,34,38,44,74$ )

Amadís de Grecia (Caballero de la Ardiente Espada, Caballero de la Muerte) (I, 1, 6, 18, 19)

Andandona (II, 25)

Arcaláus (I, 15; II, 34)

Belianís de Grecia (Caballero del Unicorno) (I, elogio, 1, 6, 13, 19, 20, 25, 52; II, 1, 18)

Cirongilio de Tracia (I, 32; II, 1)

Claradiana (I, elogio)

Caballero de la Cruz $(I, 6)$

Daraida (I, 24)

Darinel (I, 6, 24)

Elisabat (I, 24, 25, 27)

Esplandián (I, 6; II, 1, 38)

Caballero del Febo (I, elogio, 1, 15, 20)

Felixmarte (Florismarte) de Hircaña (I, 6, 13, 32, 49; II, 1)

[Florandino de Macedonia] (Caballero de las Doncellas) (I, 19)

[Florarlán de Tracia] (Caballero del Ave Fénix) (I, 19)

Fonseca $(\mathrm{I}, 6)$

[Fristón] Frestón $(I, 7,8)$

Galaor (I, 1, 13, 20, 52; II, 2)

Gandalín (I, elogio, 20)

Garaya (I, 24)

Gasabal (I, 20)

Hipólito (I, 6)

Lirgandeo (I, 43; II, 34)

Lisuarte de Grecia (II, 1)

Madásima (I, 24, 25; II, 32)

Miraguarda (I, 6)

Quirieleisón de Montalbán (I, 6)

Tomás de Montalbán (I, 6)

Olivante de Laura $(I, 6,20)$

Oriana (I, elogio, 15, 25, 26; II, 32)

Palmerín de Inglaterra (I, 1, 6; II, 1)

Palmerín de Oliva (I, 6)

Perión de Gaula (II, 1)

Pintiquiniestra (I, 6)

Placerdemivida (I, 6)

Platir (I, 9, 20)

Reposada (I, 6)

Rugel de Grecia (I, 24)

Tablante de Ricamonte (I, 16, 20)

Tinacrio el Sabidor (I, 30)

Tirante el Blanco (I, 6, 13, 20; II, 1)

Urganda la Desconocida (I, elogio, 5, 43; II, 34) 
APPENDIX IV: CHIVALRIC NAMES INVENTED BY CERVANTES IN DON QUIJOTE

\author{
A. Major names \\ Don Quijote de la Mancha (Caballero de la Triste Figura, Caballero de los Leones) \\ Dulcinea del Toboso \\ Sancho Panza (Zancas) \\ Cide Hamete Benengeli \\ Rocinante
}

B. Don Quijote's onomastic inventions

Alfeñiquén de Algarbe $(I, 18)$

Alifanfarón de la Trapobana (I, 18)

Brandabarbarán de Boliche, señor de las tres Arabias (I, 18)

Brocabruno de la Gran Fuerza (I, 21)

Caraculiambro, señor de la ínsula Malindrania (I, 1 )

Espartafilardo del Bosque, duque de Nerbia $(I, 18)$

Guadiana (II, 22, 23)

Caballero del Lago (I, 50)

Laurcalco, señor de la Puente de Plata (I, 18)

Gran Mameluco de Persia (I, 21)

Micocolembo, gran duque de Quirocia (I, 18)

Miulina (I, 18)

Pentapolín del Arremangado Brazo, rey de los Garamantes (I, 18)

Pierres Papín, señor de las Baronías de Utrique (I, 18)

Ruidera (II, 22, 23)

Caballero de la Sierpe (I, 21)

Caballero del Sol (I, 21)

Timonel de Carcajona, príncipe de la nueva Vizcaya (I, 18)

Caballero del Verde Gabán (II, 17)

C. Chivalric names created by other characters

Altisidora (Altisidorilla) (II, 44, 45, 46, 48, 50, 57, 58, 67, 69, 70, 71)

Antonomasia (II, 38, 39, 41)

Archipiela (II, 38)

Caballero de la Blanca Luna (II, 64, 65, 66)

Caballero del Bosque (Caballero de la Selva, Caballero de los Espejos) (II, 12, 13, 14, 15)

Casildea de Vandalia (II, 12, 13, 14)

Don Clavijo (II, 38, 39, 41)

Dueña Dolorida (Condesa Lobuna, Condesa Trifaldi) (II, 36, 37, 38, 39, 40, 41, 42, 44, 51)

Emerencia (II, 44)

Giralda (II, 14)

Jaramilla (I, 30)

Maguncia (II, 38, 39)

Mentironiana $(\mathrm{I}, 46)$

Princesa (Reina, Infanta) Micomicona (I, 29, 30, 35, 36, 37, 44, 46, 47)

Rey de Micomicón (Tinacrio el Sabidor) (I, 29)

Pandafilando de la Fosca Vista (I, 30)

Paralipomenón de las Tres Estrellas (II, 49)

El Roto de la Mala Figura (Caballero de la Sierra, Caballero del Bosque) (I, 23, 24)

Solisdán (I, elogio)

Trifaldín el de la Barba Blanca (II, 36, 38, 39) 
D. Corruptions of chivalric names

aquel abad (I, 25)

Don Azote (I, 30)

feo Blas (I, 15)

Cide Hamete Berengena (II, 2)

Don Diablo (I, 35)

Esquife (I, 5)

Fritón (I, 8)

Don Gigote $(I, 30)$

esa hurgada $(\mathrm{I}, 5)$

Magallanes (II, 4I)

Magimasa (I, 25)

Malandrino (I, 19)

Malino (I, 44)

Martino (I, 21)

Muñatón (I, 7)

Pandahilado (I, 30)

Don Quijote de la Manchísima (II, 38)

Don Quijotísimo (II, 38)

Señora Tobosa (I, 30)

Condesa Tres Faldas, o Tres Colas (II, 37)

Don Tonto (II, 31)

Howard Mancing

\section{University of Missouri at Columbia}

\section{NOTICE TO CONTRIBUTORS}

In accordance with its regular policy, Names furnishes gratis to its contributors 25 reprints of all longer articles and from two to five copies of notes and book reviews. Additional quantities of reprints must be ordered at least a month in advance of publication date, preferably at the time of final galley proofreading. Rates for additional copies appear below.

\begin{tabular}{|c|c|c|c|c|}
\hline \multicolumn{4}{|c|}{ Number of copies } & ditional \\
\hline Pages & 25 & 50 & 100 & 100 \\
\hline $1-4$ & 12.50 & 15.50 & 17.00 & 6.50 \\
\hline $5-8$ & 15.50 & 17.50 & 19.00 & 8.00 \\
\hline $9-12$ & 17.00 & 19.00 & 21.50 & 9.75 \\
\hline $13-16$ & 19.25 & 21.50 & 24.00 & 12.25 \\
\hline
\end{tabular}

Contributors are also reminded that, in order to facilitate typesetting, footnotes should be placed on separate sheets at the end of manuscripts. It is further recommended that contributors keep one copy of their manuscripts in case of accidental loss in the mails. 